\section{On the Presence of "Prostatic Secretion Protein" in Different Species*}

\author{
ÅKE POUSETTE, ${ }^{\mathrm{a}}$ PER BJÖRK, ${ }^{\mathrm{b}}$ \\ KJELL CARLSTRÖM ${ }^{c}{ }^{\mathrm{c}}$ BJÖRN FORSGREN, \\ JAN-ÅKE GUSTAFSSON ${ }^{\mathrm{a}}$ and \\ BERTIL HÖGBERG ${ }^{\text {b }}$
}

a Department of Chemistry and Department of Medical Nutrition, Karolinska Institutet, S-104 01 Stockholm 60, Sweden, ${ }^{b}$ Leo Research Laboratories, S-251 00 Helsingborg, Sweden and ${ }^{\mathrm{c}}$ Hormone Laboratory, Sabbatsberg Hospital, Box 6401, S-113 82 Stockholm, Sweden

Prostatic secretion protein (PSP) was discovered during investigations on the mechanism of action of estramustine phosphate, a drug used in the treatment of prostatic carcinoma. ${ }^{1}$ Distribution studies on male rats using radioactive estramustine phosphate have shown that this compound is taken up and retained by the ventral prostate lobe. ${ }^{2,3}$ Estramustine phosphate was found to bind to a specific protein in rat ventral prostate. This protein was purified to homogeneity and antibodies were raised against it. ${ }^{4} \mathrm{~A}$ radioimmunoassay was developed for quantitation of the protein and using this technique it was found that PSP was present in very high amounts in ventral prostate but was also present in lower amounts in other male sex accessory glands. ${ }^{4}$ The findings indicated that PSP is synthesized in the prostate gland and secreted into the prostatic fluid.

The biological significance of PSP is still uncertain. In order to obtain further information about this protein and its biological role, the presence of proteins immunochemically similar to PSP was studied in tissues of different species. The presence of PSP in prostate tissue from other species than rat would strengthen the contention that this protein is necessary for normal prostatic function.

Materials and methods. Tissues from mice, rats and rabbits were collected immediately after decapitation of the animals. Tissues from boars were collected at a slaughter house. Human tissues were collected at routine operations where the tissues taken for analyses had been discarded. The human prostate tissue was removed during operations for urinary bladder carcinoma. Dunning tumours were taken from rats treated as described previously. ${ }^{5}$ Preparation of cytosol and performance of radioimmunoassays (RIA) were performed as described

\footnotetext{
* Communication at the Meeting of the Swedish
} Biochemical Society in Stockholm, 29th November, 1979. previously. ${ }^{4}$ Determination of protein was carried out using bovine serum albumin as a standard. ${ }^{6}$

Results and discussion. PSP has previously been shown to make up about $20 \%$ of the protein content of rat ventral prostate cytosol. Much lower, but still significant amounts, were found in prostate tissues from other species as well as in the Dunning tumour (Tables 1 and 3). The lower amount found

Table 1. Amount of proteins immunochemically similar to PSP in prostate and seminal vesicles from different species,

\begin{tabular}{lc}
\hline Tissue & $\begin{array}{l}\text { PSP, ng/ } \\
\text { mg of cytosol protein }\end{array}$ \\
\hline Rat prostate (ventral) & 185000 \\
Rat seminal vesicles & 360 \\
Rabbit prostate & 123 \\
Rabbit seminal vesicles & 1300 \\
Boar prostate & 95 \\
Boar seminal vesicles & 208 \\
Mouse prostate & 2445 \\
Mouse seminal vesicles & 8 \\
Human prostate & 98 \\
Human seminal vesicles & 35 \\
\hline
\end{tabular}

Table 2. Amount of proteins immunochemically similar to PSP in different tissues from mouse and man.

\begin{tabular}{lcc}
\hline Tissue & \multicolumn{2}{c}{ PSP, ng/mg of cytosol protein } \\
Man & Mouse \\
\hline Prostate & 98 & 2445 \\
Seminal vesicles & 35 & 8 \\
Epididymis & 92 & 55 \\
Testis & $<1$ & 30 \\
Submaxillary gland & $<1$ & 40 \\
Kidney & $<1$ & $<1$ \\
Plasma & $<1$ & $<1$ \\
\hline
\end{tabular}

Table 3. Amount of protein immunochemically similar to PSP in five Dunning tumours.

\begin{tabular}{ll}
\hline Tumour No. & $\begin{array}{l}\text { PSP, ng/ } \\
\text { mg of cytosol protein }\end{array}$ \\
\hline 1 & 15.6 \\
2 & 15.5 \\
3 & 22.9 \\
4 & 37.5 \\
5 & 18.8 \\
\hline
\end{tabular}


may reflect a truly smaller content or may be due to insufficient cross reactivity between the tissue protein and the rat PSP antibody resulting in a falsely low value. A reliable RIA for quantitation of human PSP cannot be obtained before PSP has been purified from man and antibodies have been raised against this protein. The important finding is, however, that a protein similar to PSP is present in all prostate tissues investigated. In the rat, PSP was almost exclusively present in the male genital tract. Table 2 shows that this is true also for man and the mouse, where PSP is found in highest concentration in prostate. As PSP is tissue specific and found in all species studied, it is tempting to suggest that PSP is necessary for normal prostate function. Since prostatic diseases decrease male fertility and PSP is secreted from the prostate and is present in the ejaculate, PSP may also be of importance for normal male fertility. Studies are now in progress to elucidate possible interactions between PSP and spermatozoa, and the effect of PSP on motility and survival of spermatozoa.

Acknowledgements. This investigation was supported by a grant from "Riksföreningen mot Cancer" and the LEO Research Foundation.

1. Jönsson, G. and Högberg, B. Scand. J. Urol. Nephrol. 5 (1971) 103.

2. Appelgren, L.-E., Forsgren, B., Gustafsson, J.-Å., Pousette, $\AA$. and Högberg, B. Acta Pharmacol. Toxicol. 43 (1978) 368.

3. Forsgren, B., Gustafsson, J.-Å., Pousette, $\AA$. and Högberg, B. Cancer Res. 39 (1979) 5155.

4. Forsgren, B., Björk, P., Carlström, K., Gustafsson, J.-A., Pousette, $\AA$. and Högberg, B. Proc. Natl. Acad. Sci. U.S.A. 76 (1979) 3149.

5. Dunning, W. F. Natl. Cancer Inst. Monogr. 12 (1963) 351.

6. Lowry, O. H., Rosenbrough, N. J., Farr, A. L. and Randall, R. J. J. Biol. Chem. 193 (1951) 265.

Received November 19, 1979 